\title{
MENINGKATKAN KREATIVITAS SISWA DALAM PEMBELAJARAN IPS PADA MATERI PELAKU PEREKONOMIAN DENGAN PENERAPAN MODEL PEMBELAJARAN TEMATIK
}

\author{
Eman Sulaeman \\ SMP Negeri 1 Tambaksari, Jalan Raya Tambaksari No. 47, Ciamis, Indonesia \\ Email: emansulaeman2501@gmail.com
}

\begin{abstract}
The purpose of this research is to find out how teachers plan, implement, reflect, identify constraints, and the efforts made by the teacher to increase student creativity in overcoming obstacles in applying thematic learning models. This research method is a Classroom Action Research method. The data are collected through interviews, observations, and field notes. The research subjects are students of class VIII C SMP Negeri 1 Tambaksari. The results show that learning using thematic learning models can increase student creativity. In learning using a thematic learning model, the teacher is required to determine a theme that is in accordance with the curriculum and development of junior high school students. In the first cycle of meeting 1, student creativity can be seen from the process dimension where students quickly complete the worksheet on searching the word (creative learning). In the first cycle of meeting 2, students' creativity is more prominent in the product dimension, i.e. students make symbols and job advertisements that match their ideals. The process dimension is further increased when students conduct group discussions in the second cycle of meeting 1. In the second cycle of meeting 2, students make a product that has economic value. Based on the results of this study, it is suggested that teachers should apply a thematic learning model on different themes. So, social studies learning for the junior high school level is in accordance with the demands of the curriculum stating that social studies learning at the junior high school level must be carried out in an integrated manner so as to increase student creativity.
\end{abstract}

Keywords: Thematic Learning Model, Creativity, Social Studies Learning.

\begin{abstract}
ABSTRAK
Tujuan penelitian ini adalah untuk mengetahui bagaimana guru merencanakan, melaksanakan, merefleksikan, mengidentifikasi kendala, dan upaya yang dilakukan guru untuk meningkatkan kreativitas siswa dalam mengatasi kendala dalam menerapkan model pembelajaran tematik. Metode penelitian ini adalah metode Penelitian Tindakan Kelas. Teknik pengumpulan data dilakukan dengan wawancara, observasi, dan catatan lapangan. Subjek penelitian adalah siswa kelas VIII C SMP Negeri 1 Tambaksari. Hasil penelitian menunjukkan bahwa pembelajaran dengan menggunakan model pembelajaran tematik dapat meningkatkan kreativitas siswa. Pada pembelajaran dengan menggunakan model pembelajaran tematik guru dituntut untuk menentukan tema yang sesuai dengan kurikulum dan perkembangan siswa SMP. Pada siklus I pertemuan 1 kreativitas siswa terlihat dari dimensi proses dimana siswa dengan cepat menyelesaikan LKS mencari kata (creative learning). Siklus I pertemuan 2 kreativitas siswa lebih menonjol pada dimensi produk, yakni, siswa membuat lambang dan iklan lowongan kerja yang sesuai dengan cita-cita mereka. Dimensi proses lebih meningkat ketika siswa melakukan diskusi kelompok pada siklus II pertemuan 1. Pada siklus II pertemuan 2 siswa membuat sebuah produk yang bernilai ekonomis. Berdasarkan hasil penelitian ini disarankan untuk menerapkan model pembelajaran tematik pada tema yang berbeda sehingga pembelajaran IPS untuk tingkat SMP sesuai dengan tuntutan kurikulum yang menyatakan bahwa pembelajaran IPS pada tingkat SMP harus dilakukan secara integrasi sehingga dapat meningkatkan kreativitas siswa.
\end{abstract}

Kata Kunci: Model Pembelajaran Tematik, Kreativitas, Pembelajaran IPS.

Cara sitasi: Sulaeman, E. (2020). Upaya Meningkatkan Kreativitas Siswa dalam Pembelajaran IPS pada Materi Pelaku Perekonomian dengan Penerapan Model Pembelajaran Tematik. J-KIP (Jurnal Keguruan dan IImu Pendidikan), 1 (2), 27-32. 


\section{PENDAHULUAN}

Pembelajaran IPS yang peneliti temukan saat ini masih bersifat tradisional, dimana pusat pembelajaran hanya ada pada guru semata (teacher oriented). Siswa tidak diberikan kesempatan untuk memilih model atau metode pembelajaran yang digunakan. Kemampuan siswa baik secara lisan maupun tertulis menjadi kurang tereksplorasi di dalam kelas. Permasalahan lain yang ditemukan oleh peneliti yaitu pada saat ini pelaksanaan pembelajaran di SMP untuk mata pelajaran IPS masih dilakukan secara terpisah.

Kenyataan ini mendorong perlunya penerapan model pembelajaran yang menarik dan menyenangkan. Salah satu model pembelajaran yang dapat meningkatkan kreativitas siswa dalam pelajaran IPS adalah model pembelajaran tematik. Pembelajaran model ini akan lebih menarik dan bermakna bagi anak karena model pembelajaran ini menyajikan tema-tema pembelajaran yang lebih aktual dan kontekstual dalam kehidupan sehari-hari.

Menurut Moustakis (Munandar, 2009) kreativitas adalah pengalaman mengekspresikan dan mengaktualisasikan identitas individu dalam bentuk terpadu dalam hubungan dengan diri sendiri, dengan alam, dan dengan orang lain. Kreativitas ini ditandai oleh adanya kegiatan menciptakan sesuatu yang sebelumnya tidak ada dan dilakukan oleh seseorang atau adanya kecenderungan untuk menciptakan sesuatu.

Model pembelajaran tematik yang dimaksud dalam penelitian ini yaitu pembelajaran yang dikemas dalam suatu tema atau bisa disebut dengan istilah tematik yang berasal dari integrasi antara satu Kompetensi Dasar dengan Kompetensi Dasar lainnya yang sesuai dengan silabus dan pembelajaran IPS. Pendekatan tematik ini merupakan satu usaha untuk mengintegrasikan pengetahuan, kemahiran dan nilai pembelajaran serta pemikiran yang kreatif dengan menggunakan tema. Dengan kata lain pembelajaran tematik adalah pembelajaran yang menggunakan tema dalam mengaitkan beberapa konsep disiplin ilmu sosial sehingga dapat memberikan pengalaman bermakna bagi siswa. Dikatakan bermakna karena dalam pembelajaran tematik, siswa akan memahami konsepkonsep yang mereka pelajari melalui pengalaman langsung dan menghubungkannya dengan konsep lain yang telah dipahaminya.

Model pembelajaran ini berangkat dari teori pembelajaran yang menolak proses latihan/hafalan (drill) sebagai dasar pembentukan pengetahuan dan struktur intelektual anak. Model pembelajaran tematik lebih menekankan pada penerapan konsep belajar sambil melakukan sesuatu (learning by doing) (Trianto, 2010). Tema yang dijadikan fokus pembelajaran diambil berdasarkan Standar Kompetensi dan Kompetensi Dasar yang telah disusun oleh Badan Nasional Standar Pendidikan (BSNP). Tema pada pembelajaran IPS kemudian dikembangkan menjadi beberapa konsep dan ditindaklanjuti dengan berbagai aktifitas belajar siswa yang mengarahkan pada peningkatan kreativitas siswa itu sendiri.

Model pembelajaran tematik ini sangat cocok bagi siswa untuk meningkatkan kreativitasnya. Setelah siswa menyelesaikan satu tema mereka dapat memutuskan pemecahan masalah secara kreatif atau membuat produk berupa rangkuman, kerajinan tangan, karya tulis sederhana, atau karya seni lainnya yang dipresentasikan di depan kelas. Pembelajaran tematik juga memiliki peluang untuk meningkatkan kreativitas akademik maupun non akademik. Hal ini disebabkan model ini menekankan pada peningkatan kemampuan analitis terhadap konsep-konsep yang dipadukan. Menurut Depdikbud (1996) model pembelajaran tematik adalah pendekatan pembelajaran yang memungkinkan siswa baik secara individual maupun kelompok, aktif mencari, menggali, dan menemukan konsep serta prinsip secara holistik dan otentik. Namun demikian, masih banyak pihak yang belum memahami dan mampu menerapkan model pembelajaran ini secara baik.

Kegiatan pembelajaran masih bepusat pada guru (teacher oriented). Serta guru masih kesulitan untuk mengintegrasikan pembelajaran, karena background guru yang bukan dari lulusan sarjana IPS. Hal ini menyebabkan siswa kurang memahami materi secara keseluruhan yang 
mengakibatkan kurangnya pemahaman konsep siswa terhadap mata pelajaran IPS, sehingga kreativitas siswa pun rendah.

Penelitian ini dilatarbelakangi oleh hasil observasi terhadap kelas VIII C SMP Negeri 1 Tambaksari pada tanggal 26 Februari 2019. Berdasarkan hasil observasi, peneliti menemukan permasalahan yang dihadapi selama proses pembelajaran IPS di sekolah yaitu terlalu banyaknya konsep dalam materi pembelajaran IPS, sehingga siswa lebih mementingkan pengetahuannya saja dengan cara menghafal berbagai konsep dan siswa kurang mampu mengembangkan konsep tersebut dengan kehidupan nyata yang mereka hadapi sehari-hari. Sistem pendidikan seperti ini membuat anak berpikir secara parsial dan terkotak-kotak, sehingga pada akhirnya dapat mematikan kreativitasnya.

Kreativitas siswa di SMP Negeri 1 Tambaksari khususnya kelas VIII C ini rendah, hal ini disebabkan kerena siswa kurang mengekspresikan pengalamannya baik secara lisan maupun tertulis. Siswa tidak pernah diberi kesempatan untuk mengemukakan gagasan-gagasan yang baru. Pembelajaran pun lebih didominasi oleh guru, sehingga siswa tidak pernah bertanya tentang materi yang belum mereka pahami. Guru merasa tidak mempunyai banyak waktu dalam mengembangkan kreativitas siswa ini sehingga tidak menjadi prioritas utama dalam pembelajaran IPS.

Hal tersebut sejalan dengan hasil wawancara peneliti dengan guru mitra Bapak Sukiman, S.Pd.Bio., dan Bapak Ahmad Kurniawan, S.Pd. Beliau merasa cukup kesulitan dalam mengintegrasikan pelajaran IPS di SMP, karena pelajaran IPS materinya sangat luas, sehingga dalam pembelajaran IPS, konsep disiplin ilmu sejarah lebih mendominasi dalam proses pembelajaran dikelas yang pada akhirnya menyebabkan konsep IPS yang disampaikan guru menjadi terpisah-pisah. Masalah rendahnya kreativitas siswa dalam pembelajaran IPS tersebut, terkait langsung dengan kemampuan guru itu sendiri untuk berinovasi khususnya dalam mengembangkan model pembelajaran. Latar belakang pendidikan ilmu sosial pada guru IPS di tingkat SMP menjadi salah satu kendala bagi guru untuk menyelenggarakan pendidikan secara terintegrasi.

Dengan permasalahan tersebut, melalui penelitian ini diharapkan dapat memperbaiki proses pembelajaran IPS. Karena penelitian ini dilakukan secara kolaboratif yang menyertakan guru sebagai subjek penelitian, sehingga pada akhirnya di samping memperkenalkan model pembelajaran tematik, juga secara substansial dapat meningkatkan kualitas proses pembelajaran IPS terutama untuk meningkatkan kreativitas siswa.

\section{METODE PENELITIAN}

Metode penelitian pada kegiatan penelitian ini menggunakan Penelitian Tindakan Kelas. Menurut Suryabrata (Mahmud \& Priatna, 2008) Penelitian tindakan adalah penelitian yang bertujuan untuk mengembangkan keterampilan-keterampilan baru, strategi baru atau pendekatan baru untuk memecahkan masalah dengan penerapan langsung di dunia kerja atau dunia aktual yang lain. Penelitian tindakan merupakan penelitian yang diarahkan untuk memecahan masalah atau perbaikan. Guru-guru mengadakan pemecahan terhadap masalah-masalah yang dihadapi dalam kelas, kepala sekolah mengadakan perbaikan terhadap manajemen di sekolahnya. Penelitian ini difokuskan kepada perbaikan proses maupun peningkatan hasil kegiatan. Kegiatannya dilakukan di SMP Negeri 1 Tambaksari yang berlokasi di Jalan Raya Tambaksari No. 47 Kecamatan Tambaksari Kabupaten Ciamis untuk mata pelajaran IImu Pengetahuan Sosial kelas VIII C.

\section{HASIL DAN PEMBAHASAN}

Berdasarkan hasil pengamatan diperoleh temuan sebagai berikut, siklus I pertemuan 1 yang menyatakan ya sebesar $69,23 \%$ dan yang menyatakan tidak $30,77 \%$, siklus I pertemuan 2 yang menyatakan ya sebesar $84,62 \%$ dan yang menyatakan tidak sebesar $15,38 \%$, siklus II pertemuan 1 yang menyatakan ya sebesar $92,31 \%$ dan yang menyatakan tidak sebesar $7,69 \%$, dan siklus II pertemuan 2 yang menyatakan ya sebesar $100 \%$. Berdasarkan hasil temuan pengamat dapat dilihat pada Gambar 1. 


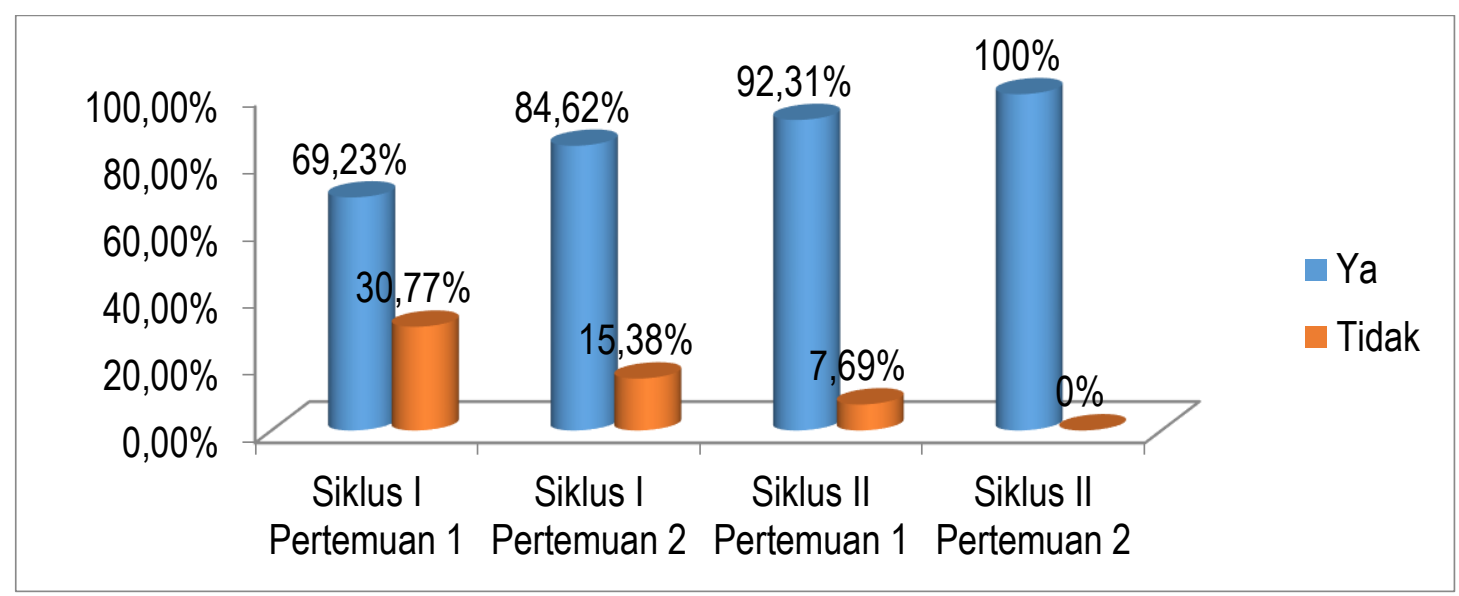

Gambar 1. Grafik Hasil Pengamatan Aktivitas Guru

\section{Aktivitas Siswa}

Berdasarkan hasil pengamatan diperoleh temuan yang dapat dilihat pada Tabel 1 .

Tabel 1. Rekapitulasi Aktivitas Siswa Selama Pembelajaran Siklus I dan Siklus II

\begin{tabular}{cccccc}
\hline Siklus & A & B & Aspek yang diamati & D & E \\
\hline S I /P1 & $57,14 \%$ & $35,71 \%$ & $39,29 \%$ & $28,57 \%$ & $53,57 \%$ \\
S I /P2 & $64,29 \%$ & $42,86 \%$ & $46,43 \%$ & $35,71 \%$ & $60,71 \%$ \\
S II /P1 & $71,43 \%$ & $50 \%$ & $53,57 \%$ & $46,43 \%$ & $67,86 \%$ \\
S II /P2 & $89,29 \%$ & $57,14 \%$ & $71,43 \%$ & $60,71 \%$ & $85,71 \%$ \\
\hline
\end{tabular}

Keterangan :
A. Memperhatikan penjelasan guru
B. Berdiskusi atau bertanya jawab dengan teman dalam kelompok
C. Keberanian mengemukakan pendapat
D. Berani tampil di depan kelas, mempresentasikan hasil pekerjaanya
E. Mengerjakan evaluasi secara sungguh-sungguh

Berdasarkan pembahasan dari hasil penelitian bahwa pada penelitian tindakan kelas aktivitas siswa dapat meningkat dari setiap siklus.

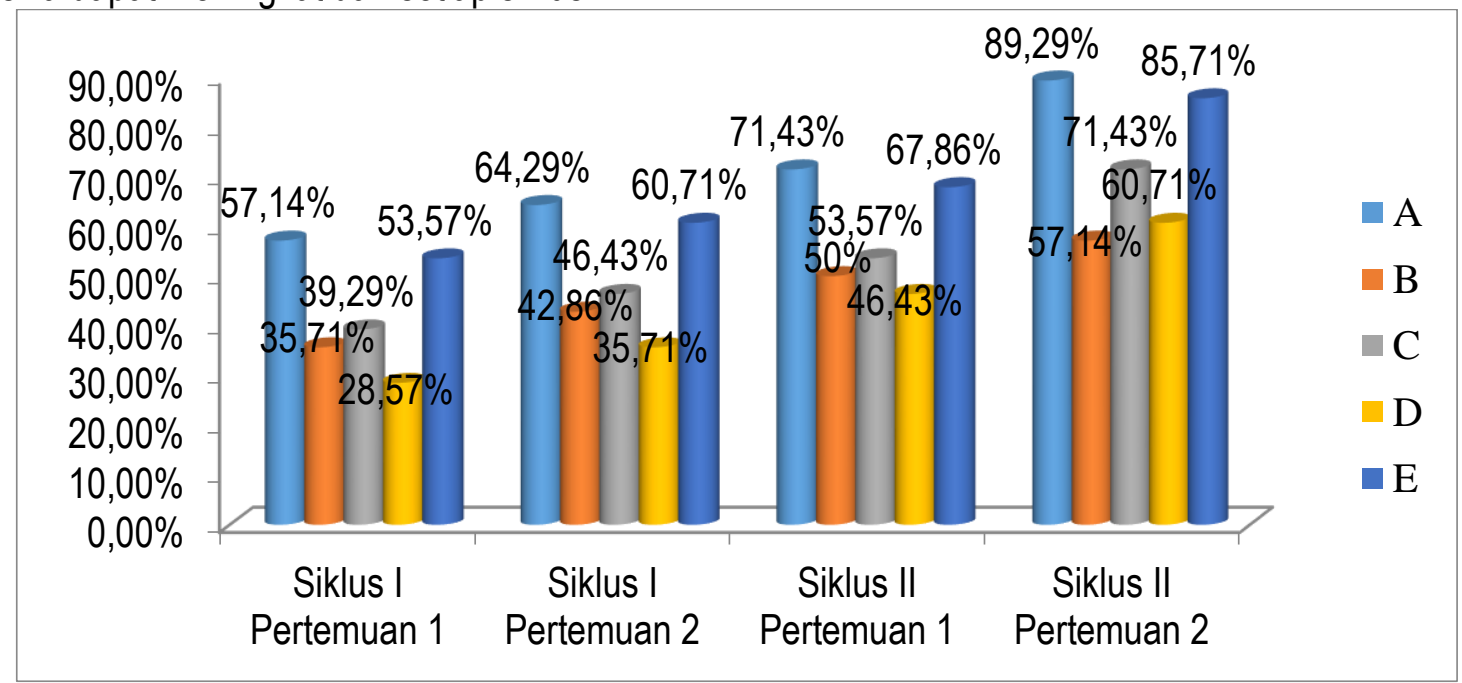

Gambar 2. Grafik Hasil Pengamatan Aktivitas Siswa Selama Pembelajaran 
Keterangan :
A. Memperhatikan penjelasan guru
B. Berdiskusi atau bertanya jawab dengan teman dalam kelompok
C. Keberanian mengemukakan pendapat
D. Berani tampil di depan kelas, mempresentasikan hasil pekerjaanya
E. Mengerjakan evaluasi secara sungguh-sungguh

\section{Keterlaksanaan Pembelajaran}

Keterlaksanaan proses pembelajaran dengan menggunakan model pembelajaran tematik pada setiap siklus dalam penelitian ini mengalami kenaikan yaitu siklus I pertemuan 1 ketuntasan belajar 15 orang siswa $(53,57 \%)$ dengan rata-rata 68,04 . Siklus I pertemuan 2 ketuntasan belajar 20 orang siswa $(71,43 \%)$ dengan rata-rata hasil belajar 73,93 . Siklus II pertemuan 1 ketuntasan belajar 22 orang $(78,57 \%)$ rata-rata hasil belajar 80,54 . Siklus II pertemuan 2 ketuntasan belajar 26 orang $(92,86 \%)$ rata-rata hasil belajar 85,71 . Untuk melihat perbandingan peningkatan keterlaksanaan pembelajaran dapat dilihat pada grafik dibawah ini, yaitu perbandingan ketuntasan belajar dan perbandingan rata-rata kelas.

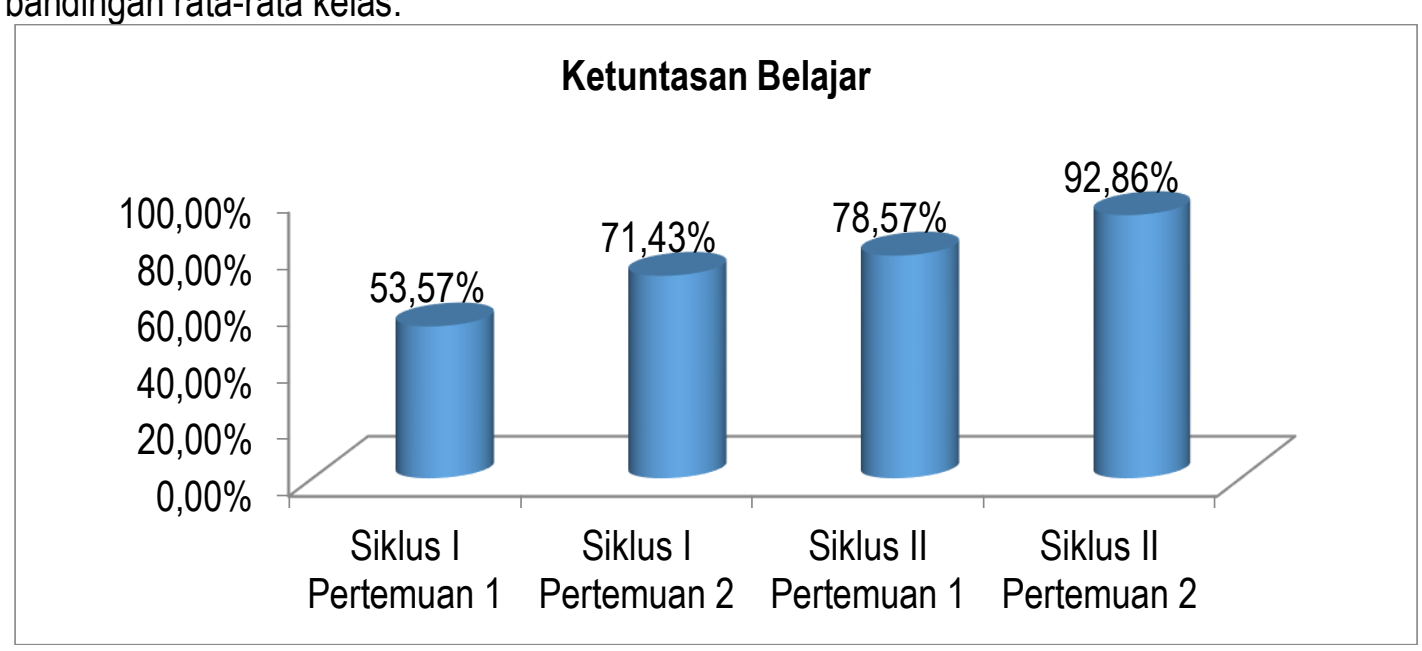

Gambar 3. Grafik Ketuntasan Belajar

Melihat grafik hasil penelitian pada Gambar 3 maka terjadi kenaikan keterlaksanaan pembelajaran dalam ketuntasan belajar, yaitu $17,86 \%$ dari siklus I pertemuan 1 ke siklus I pertemuan $2,7,14 \%$ dari siklus I pertemuan 2 ke siklus II pertemuan 1,14,29\% dari siklus II pertemuan 1 ke siklus II pertemuan 2.

\section{Rata-rata Hasil Belajar}

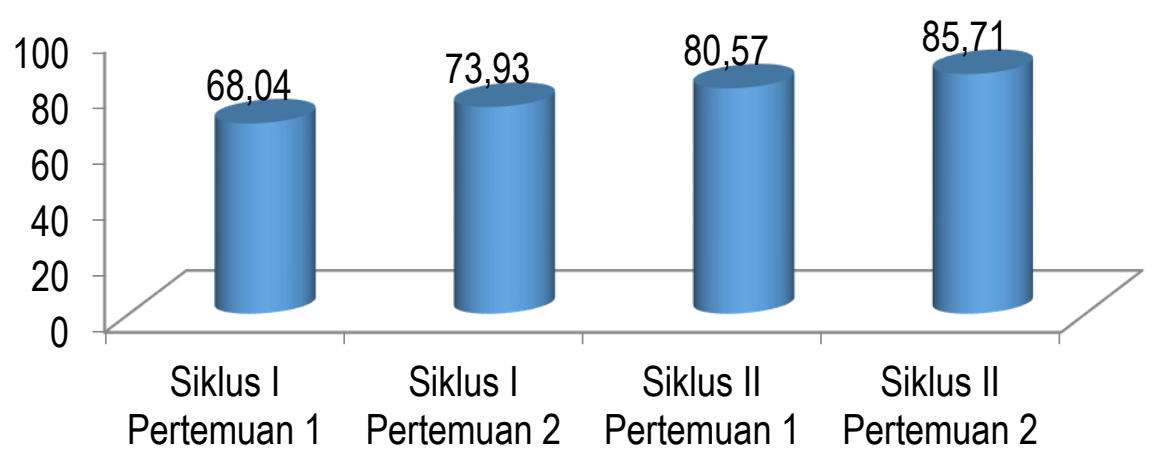

Gambar 4. Grafik Rata-Rata Hasil Belajar 
Melihat grafik pada Gambar 4 diperoleh rata-rata hasil tes belajar terjadi kenaikan rata-rata hasil belajar siswa, yaitu rata-rata 5,89 dari siklus I pertemuan 1 ke siklus I pertemuan 2, rata-rata 6,61 dari siklus I pertemuan 2 ke siklus II pertemuan 1, rata-rata 5,18 dari siklus II pertemuan 1 ke siklus II pertemuan 2.

Mengingat proses pembelajaran antar siklus dapat meningkat maka tindakan selanjutnya dihentikan karena sudah mencapai hasil ketuntasan belajar maksimal $85 \%$. Namun masih ada siswa yang nilaianya dibawah ketuntasan belajar sekitar $7,14 \%$ atau 2 orang.

\section{KESIMPULAN}

Berdasarkan lembar observasi dan hasil analisis data terhadap hasil tes, maka dapat dibuat kesimpulan: a) Keterlaksanaan pembelajaran dengan menggunakan model pembelajaran tematis pada siswa kelas VIII C SMP Negeri 1 Tambaksari mengalami peningkatan pada setiap siklusnya, kenaikan keterlaksanaan pembelajaran dalam ketuntasan belajar, yaitu $17,86 \%$ dari siklus I pertemuan 1 ke siklus I pertemuan 2, 7,14\% dari siklus I pertemuan 2 ke siklus II pertemuan 1, 14,29\% dari siklus II pertemuan 1 ke siklus II pertemuan; b) Penerapan model pembelajaran tematis pada pembelajaran IPS dapat meningkatkan hasil belajar siswa kelas VIII C SMP Negeri 1 Tambaksari yang ditunjukkan dengan adanya peningkatan ketuntasan klasikal pada setiap siklusnya, yaitu rata-rata 5,89 dari siklus I pertemuan 1 ke siklus I pertemuan 2, rata-rata 6,61 dari siklus I pertemuan 2 ke siklus II pertemuan 1, rata-rata 5,18 dari siklus II pertemuan 1 ke siklus II pertemuan 2 ; c)Keterlaksanaan pembelajaran dan ketuntasan klasikal tercapai pada siklus ke II pertemuan 2 .

\section{REKOMENDASI}

Berdasarkan hasil penelitian, peneliti mengajukan saran-saran dengan harapan dapat berguna untuk meningkatkan kreativitas siswa, khususnya untuk pelajaran IPS. Peneliti memberikan saran sebagai berikut : a) Pengelolaan waktu harus dikelola dengan baik, sehingga setiap tahapan dalam model pembelajaran ini dapat terlaksana dengan baik; b) Model pembelajaran tematik sesuai diterapkan untuk penemuan konsep fisika hanya kemampuan berhitung masih banyak menjadi kendala; c) Sebaiknya rekan guru yang bertugas sebagai pengamat penelitian tindakan kelas adalah guru pengajar pada tingkat kelas yang sama agar memahami materi yang disampaikan sehingga pada saat siswa menjawab pertanyaan arahan dari guru dapat mengetahui apakah jawaban sudah sesuai atau belum.

\section{UCAPAN TERIMAKASIH}

Ucapan terimakasih ditujukan kepada kepala sekolah SMP Negeri 1 Tambaksari yang telah memebrikan izin terhadap pelaksanaan penelitian ini. Selanjutnya ucapan terimakasih ditujukan kepada kelas VIII C yang telah mendukung terhadap pelaksanaan penelitian ini.

\section{DAFTAR PUSTAKA}

Depdikbud. (1996). Penelitian Tindakan Kelas. Jakarta: Puskur Balitbang Depdiknas Prov. Jabar.

Mahmud \& Priatna, T. (2008). Penelitian Tindakan kelas (Teori dan Praktik). http://digilib.uinsgd.ac.id/9635/1/FINAL\%20BUKU\%20PTK\%20PENELITIAN\%20KELAS.pd f. Diakses tanggal 5 Oktober 2020.

Munandar, U. (2009). Pengembangan Kreativitas Anak Berbakat. Jakarta: Rineka Cipta.

Trianto. (2010). Model Pembelajaran Terpadu. Jakarta: Bumi Aksara. 